\title{
KORELASI KESULITAN BELAJAR DENGAN PRESTASI BELAJAR SISWA PADA MATA PELAJARAN COMPUTER NUMERICAL CONTROL SISWA SMK
}

\author{
Nur Ihwan ${ }^{1}$, Syafaruddin Siregar ${ }^{2}$, Wardaya $^{3}$ \\ Departemen Pendidikan Teknik Mesin \\ Universitas Pendidikan Indonesia \\ Jl. Dr. Setiabudhi No. 207 Bandung 40154 \\ nurihwan01@yahoo.co.id
}

\begin{abstract}
ABSTRAK
Tujuan penelitian ini untuk mengetahui seberapa besar korelasi kesulitan belajar dengan prestasi belajar siswa pada mata pelajaran Computer Numerical Control (CNC) di SMK Negeri 12 Bandung dan untuk mengetahui Faktor manakah yang lebih dominan yang menjadi penyebab kesulitan belajar siswa pada mata pelajaran Computer Numerical Control (CNC) di SMK Negeri 12 Bandung. Metode yang digunakan dalam penelitian ini adalah menggunakan pendekatan metode deskriptif analitik korelasional, metode ini untuk mengetahui ada tidaknya hubungan antara dua variabel atau lebih. Pengumpulan data yang digunakan adalah angket (kuesioner) dengan menggunakan cara sampel proporsional acak sederhana dengan cara diundi tanpa pengembalian, dan nilai akhir dari sekolah (dokumentasi). Hasil temuan dalam penelitian ini yaitu terdapat hubungan yang signifikan antara Kesulitan Belajar terhadap prestasi belajar siswa pada mata pelajaran CNC bubut pada siswa kelas XI PPU di SMKN 12 Bandung tahun ajaran 2013/2014. Untuk rekomendasi yaitu lebih meningkatkan kemampuan aspek kognitif untuk penguasaan teori CNC serta meningkatkan kemampuan pada aspek psikomotor (keterampilan) dalam praktek permesinan dan memahami kesulitan belajar dan mencari jalan keluarnya.
\end{abstract}

Kata kunci: kesulitan, prestasi, belajar, CNC, kejuruan

\section{PENDAHULUAN}

Proses pendidikan pada hakikatnya merupakan suatu proses pembinaan sumber daya manusia yang ditekankan pada upaya pengembangan aspek-aspek pribadi peserta didik baik dari segi jasmani maupun rohaninya. Manusia sebagai peserta didik akan mendapatkan pengalaman-pengalaman yang baru yang berkaitan dengan pola-pola tingkah lakunya, sehingga akan membentuk perilaku manusia itu sendiri (Syah, 2004). Sekolah Menengah Kejuruan (SMK) yang merupakan suatu lembaga pendidikan formal dimana lulusannya dipersiapkan untuk memasuki dunia kerja dan memiliki kemampuan yang sesuai dengan kebutuhan industri. Untuk mencapai tujuan tersebut, maka dalam kurikulum program keahlian teknik pemesinan telah disusun beberapa mata pelajaran yang harus ditempuh oleh peserta diklat, salah satunya adalah mata pelajaran Computer Numerical Control $(C N C)$. Prestasi belajar yang dicapai siswa merupakan hasil belajar yang dipengaruhi oleh diri siswa sendiri dalam interaksinya dengan lingkungan. Prestasi belajar ini menunjukkan gambaran keberhasilan dalam upaya mengoptimalkan kemampuan yang

\footnotetext{
${ }^{1}$ Mahasiswa Departemen Pendidikan Teknik Mesin FPTK UPI

${ }^{2}$ Dosen Departemen Pendidikan Teknik Mesin FPTK UPI

${ }^{3}$ Dosen Departemen Pendidikan Teknik Mesin FPTK UPI
} 
dimilikinya dalam mengikuti mata pelajaran $\mathrm{CNC}$, dengan pertimbangan tersebut, diharapkan siswa bersangkutan dapat mencapai prestasi belajar yang maksimal.

Namun pada kenyataannya di lapangan secara umum masih ditemukan siswa yang belum sepenuhnya dapat mengembangkan potensi secara optimal sebagaimana yang diharapkan (Sudjana, 2002). Melihat kenyataan yang ada bahwa berdasarkan data dari guru SMKN 12 Bandung mengenai hasil prestasi belajar mata pelajaran CNC di SMK Negeri 12 Bandung, masih terdapat prestasi belajar siswa yang masih kurang memuaskan.

Belum adanya nilai yang mencapai nilai A, bahkan masih ada yang belum lulus dari hasil belajar peserta diklat kelas XI SMK Negeri 12 Bandung pada mata pelajaran CNC, bisa dilihat dengan persentase nilai mata pelajaran CNC. Siswa yang tidak lulus sebanyak $4,8 \%$ dan siswa yang lulus amat baik sebanyak $0 \%$. Idealnya nilai praktek CNC haruslah pada kualifikasi A. Kenyataan di lapangan masih adanya siswa mendapatkan nilai D yaitu sebanyak 4,8\%. Untuk itu diupayakan para peserta didik dapat meningkatkan nilai B, C dan D menjadi nilai A. Tujuan penelitian ini, yaitu: untuk memperoleh gambaran terdapat atau tidaknya hubungan faktor kesulitan belajar terhadap prestasi belajar pada mata pelajaran $\mathrm{CNC}$, gambaran seberapa besar pengaruh kesulitan belajar siswa terhadap prestasi belajar siswa pada mata pelajaran $\mathrm{CNC}$, dan gambaran tentang faktor dominan kesulitan belajar siswa terhadap prestasi belajar pada mata pelajaran CNC.

\section{METODE PENELITIAN}

Metode penelitian yang digunakan adalah metode deskriptif korelasional. Penelitian ini mendeskripsikan variabel yang diteliti, besar korelasi kesulitan belajar terhadap prestasi belajar siswa pada mata pelajaran CNC. Penelitian ini dilaksanakan di SMK Negeri 12 Bandung tahun ajaran 2013/2014.

\section{HASIL PENELITIAN}

Terdapat hubungan secara linear antara kesulitan dalam belajar dengan prestasi belajar siswa pada mata pelajaran CNC bubut pada siswa kelas XI PPU di SMKN 12 Bandung tahun ajaran 2013/2014. Sedangkan untuk pengujian keberartian koefisien regresi, sebagai berikut: nilai $\mathrm{t}$ hitung konstanta sebesar 3,559 untuk taraf signifikansi sebesar 5\% nilai $t_{\text {tabel }}$ di dapat adalah 1,699 maka dapat menolak $\mathrm{H}_{\mathrm{o}}$ dan menerima $\mathrm{Ha}$ atau

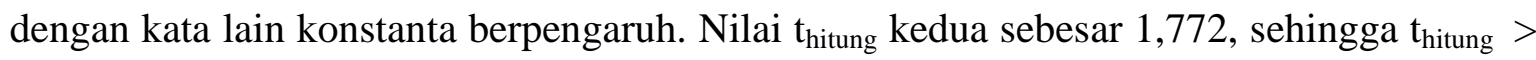
$\mathrm{t}_{\text {tabel }}=1,772>1,699$, maka $\mathrm{H}_{\mathrm{o}}$ ditolak dan Ha diterima atau dengan kata lain kesulitan 
dalam belajar akan berpengaruh terhadap prestasi belajar siswa pada mata pelajaran CNC bubut pada siswa kelas XI PPU di SMKN 12 Bandung tahun ajaran 2013/2014. Nilai R yang merupakan simbol dari nilai koefisien korelasi. Pada hasil di atas nilai korelasi adalah 0,313. Nilai ini dapat diinterpretasikan menurut kriteria derajat korelasi Syafaruddin Siregar (2004:295) adalah bahwa hubungan kedua variabel penelitian ada di kategori korelasi rendah.

Kriteria linieritas dapat ditentukan berdasarkan uji F atau uji nilai Signifikansi (Sig.). Cara yang paling mudah yaitu dengan uji Sig., dengan ketentuan apabila nilai Sig. < 0,05, maka model regresi adalah linier, dan berlaku sebaliknya. Berdasarkan tabel ketiga, diperoleh nilai Sig. $=0,047$ yang berarti lebih kecil dari kriteria signifikan $(0,047<0,05)$, dengan demikian model persamaan regresi berdasarkan data penelitian ini adalah signifikan artinya, model regresi linier memenuhi kriteria linieritas.

Pengujian korelasi dengan menggunakan metode korelasi product momen dari Pearson diperoleh harga $r=0,313$. Jika harga tersebut di konsultasikan menggunakan kriteria penafsiran koefisien korelasi, ternyata menunjukkan korelasi yang rendah. Dari hasil perhitungan diperoleh koefisien korelasi sebesar 0,313 dan $t_{\text {hitung }}$ sebesar 1,772. Pada taraf kepercayaan 95\% dengan $\mathrm{dk}=30$ dari tabel diperoleh $\mathrm{t}_{\text {tabel }}$ sebesar : $\mathrm{t}_{(0,95)(29)}=1,699$. Ternyata $t_{\text {hitung }}>t_{\text {tabel}}$, atau 1,772 > 1,699 sehingga Ho ditolak, artinya dapat disimpulkan bahwa terdapat korelasi antara kesulitan belajar dengan prestasi belajar siswa pada mata pelajaran CNC bubut pada siswa kelas XI PPU di SMKN 12 Bandung tahun ajaran 2013/2014, atau korelasi bersifat nyata dan signifikan. Nilai dari koefisien determinasi, menunjukkan bahwa sebanyak 9,8\% Variabel Kesulitan belajar Siswa (X) yang mempengaruhi variabel prestasi belajar siswa pada mata pelajaran CNC bubut pada siswa kelas XI PPU di SMKN 12 Bandung tahun ajaran 2013/2014 sedangkan variabel sisanya $90,2 \%$ dipengaruhi variabel lain.

\section{PEMBAHASAN}

Hasil penelitian menunjukkan bahwa kesulitan belajar di SMK Negeri 12 Bandung mencapai 9,8\%. Artinya besarnya pengaruh yang diberikan oleh variabel $\mathrm{X}$ terhadap variabel $\mathrm{Y}$ sebesar 9,8\% dan sisanya adalah 90,2\% dipengaruhi oleh faktor lain. Begitu pula dengan hasil pengolahan data dan analisis data hasil penelitian menunjukkan adanya korelasi kesulitan belajar dengan prestasi belajar siswa pada mata pelajaran CNC di SMK Negeri 12 Bandung. 
Faktor terbesar yang berpengaruh prestasi belajar adalah faktor lain selain kesulitan belajar. Untuk meningkatkan prestasi belajar tidak hanya tergantung dari motivasi, kebiasaan belajar dan lingkungan belajar, melainkan dari beberapa faktor seperti metode dalam belajar mengajar, keadaan ekonomi keluraga, minat dan masih banyak faktor lainnya. Faktor lain yang mempengaruhi kesulitan belajar adalah metode mengajar, metode pembelajaran merupakan salah satu kompetensi, yang harus dikuasai oleh Guru apabila proses belajar mengajar yang dilakukan ingin berjalan dengan baik. Metode pembelajaran juga diartikan sebagai suatu cara yang terstruktur yang digunakan oleh guru dalam proses belajar mengajar, untuk mencapai tujuan pendidikan. Untuk itu pemilihan metode pembelajaran yang tepat akan sangat membantu tingkat ketercapaian tujuan pembelajaran yang telah ditetapkan.

Selain faktor metode belajar mengajar, keadaan ekonomi bisa mempengaruhi kesulitan belajar, keadaan ekonomi keluarga erat hubungannya dengan belajar siswa. Masalah biaya menjadi sumber kekuatan belajarnya, kurangnya biaya akan mengganggu kelancaran studinya. Siswa yang sedang belajar selain harus terpenuhi pokoknya, misal makan, pakaian, perlindungan kesehatan dan lain-lain, juga membutuhkan fasilitas belajar seperti ruang belajar, meja, kursi, penerangan, alat tulis menulis, buku-buku dan lain-lain. Fasilitas belajar itu hanya dapat terpenuhi jika keluarga mempuyai cukup uang (Slameto, 2010).

Minat juga bisa mempengaruhi kesulitan belajar. Minat adalah kecenderungan yang tetap untuk memperhatikan dan mengenang beberapa kegiatan. Minat mengandung unsurunsur pengenalan (kognitif), emosi (afektif) dan kemampuan (konatif) untuk mencapai suatu objek. Minat besar pengaruhnya terhadap belajar, karena bila bahan pelajaran yang dipelajari tidak sesuai dengan minat siswa, siswa tidak akan belajar dengan sebaikbaiknya, karena tidak ada daya tarik baginya. Bahan pelajaran yang menarik minat siswa, lebih muda dipelajari dan disimpan, karena minat menambah kegiatan belajarnya. Faktor yang mempengaruhi belajar digolongkan menjadi dua, yaitu internal dan eksternal. Faktor internal adalah faktor yang ada dalam diri individu yang sedang belajar, sedangkan faktor eksternal adalah faktor yang ada di luar individu.

Alat pelajaran meliputi buku pelajaran, buku bacaan, alat dan fasilitas laboratorium dan berbagai media pengajaran yang lain. Untuk bidang ilmu keteknikan, tersedianya sarana yang memadai untuk praktikum sangat diperlukan. Kekurangan sarana pembelajaran dapat menghambat studi para siswa. Hal ini dikarenakan sarana 
pembelajaran yang lengkap dan tepat akan memperlancar penerimaan bahawa mata pelajaran yang diberikan.

Tidak bisa disangkal bahwa dalam belajar seseorang dipengaruhi oleh banyak faktor. Bagi pelajar sendiri adalah penting untuk mengetahui faktor-faktor yang dimaksud. Hal ini menjadi lebih penting lagi tidak hanya bagi pelajar tetapi juga bagi calon pendidik, pengajar di dalam mengatur dan mengendalikan faktor-faktor yang mempengaruhi belajar sedemikian hingga dapat terjadi proses belajar yang optimal (Cartono dan Utari, 2006).

Keseluruhan proses belajar mengajar terjadilah interaksi antara berbagai komponen. Masing-masing komponen diusahakan saling pengaruh-mempengaruhi sedemikian hingga dapat tercapai tujuan pendidikan dan pengajaran. Salah satu komponen yang utama adalah siswa, hal itu dapat dipahami karena yang harus mencapai tujuan adalah siswa dan oleh karena itu siswalah yang harus belajar (Surakhmad, 1994). Pemahaman terhadap siswa adalah penting bagi guru maupun pembimbing dapat menciptkan situasi yang tepat serta memberi pengaruh yang optimal bagi siswa untuk dapat belajar yang berhasil.

\section{KESIMPULAN}

Kesimpulan penelitian ini, sebagai berikut: terdapat hubungan yang rendah antara kesulitan Belajar dengan prestasi belajar siswa pada mata pelajaran CNC bubut. Kesulitan belajar mempengaruhi prestasi belajar siswa sebesar 9,8\%. Sebesar 90,2\% kesulitan belajar siswa dipengaruhi oleh faktor lain. Kesulitan belajar terdapat faktor dominan yang mempengaruhi prestasi belajar yaitu kebiasaan belajar sebesar 40,55\%.

\section{DAFTAR PUSTAKA}

Cartono \& Utari, T.S.G. (2006). Penilaian Hasil Belajar Berbasis Standar. Bandung: Prima Press Prodaktama.

Slameto. (2010). Belajar dan Faktor-faktor yang Mempengaruhinya. Jakarta: Bina Aksara.

Syah, M. (2004). Psikologi Belajar. Jakarta: Raja Grafindo Persada.

Sudjana, N. (2002). Penelitian Hasil Proses Belajar Mengajar. Bandung: Remaja Rosdakarya.

Surakhmad, W. (1994). Pengantar Penelitian Ilmiah Dasar Metode Teknik. Bandung: Tarsito. 